\title{
HUBUNGAN TINGKAT PENGETAHUAN DENGAN KEJADIAN ULKUS DIABETIK PADA PASIEN DIABETES MELLITUS DI RUANG SERUNI RSUD DR. M. YUNUS BENGKULU
}

\author{
Hanifah, Dian Dwiana, Patria, Buyung Keraman \\ Program Studi IImu Keperawatan STIKES Tri Mandiri Sakti, Jl. Hibrida No 3 Sido Mulyo Bengkulu \\ Email:ns hanifah@yahoo.com
}

\begin{abstract}
ABSTRAK
Diabetes Melitus adalah penyakit yang ditandai dengan terjadinya hiperglikemia dan gangguan metabolisme karbohidrat, lemak, dan sekresi insulin dengan gejala polidipsia, poliuria, polifagia dan kesemutan. Indonesia termasuk dalam peringkat 6 angka kejadian diabetes melitus terbanyak di dunia.Tujuan penelitian adalah untuk mengetahui hubungan tingkat pengetahuan dengan kejadian ulkus diabetik pada pasien Diabetes Mellitus (DM)di Ruang Seruni RSUD Dr. M. Yunus Bengkulu. Jenis penelitian ini adalah deskriptif korelasi dengan pendekatan cross sectional. Populasi adalah seluruh pasien DM di Ruang Seruni RSUD Dr. M. Yunus Bengkulu dengan teknik accidental sampling sebanyak 36 orang.Tehnikanalisis data menggunakan uji statistic chi-square dan untuk mengetahui keeratan hubungan menggunakan uji contingency coefficient. Hasil didapatkan 12 orang (33,3\%) mengalami ulkus diabetikum dan 24 orang $(66,7 \%)$ tidak mengalami ulkus diabetikum. Terdapat 9 orang $(25,0 \%)$ dengan pengetahuan kurang, 12 orang $(33,3 \%)$ dengan pengetahuan sedang dan 15 orang $(41,7 \%)$ dengan pengetahuan baik. Ada hubungan antara tingkat pengetahuan pasien dengan kejadian ulkus diabetik pada pasien DM di Ruang Seruni RSUD Dr. M. Yunus Bengkulu. dengan kategori hubungan sedang. Diharapkan perawat dapat memberikan informasi dan pendidikan kesehatan tentang Diabetes Mellitus dan pencegahan komplikasinya kepada pasien dan keluarga.
\end{abstract}

Kata Kunci : pengetahuan; ulkus diabetikum; diabetes mellitus

\begin{abstract}
Diabetes mellitus is a disease characterized by hyperglycemia and impaired metabolism of carbohydrates, fats, and insulin secretion with symptoms of polydipsia, polyuria, polyphagia and tingling. Indonesia is ranked 6 th in the highest incidence of diabetes mellitus in the world. The purpose of this study was to determine the relationship of the level of knowledge with the incidence of diabetic ulcers in patients with Diabetes Mellitus (DM) in Seruni Room Dr. M. Yunus Bengkulu. This type of research is descriptive correlation with cross sectional approach. The population was all DM patients in Seruni Room Dr. M. Yunus Bengkulu with 36 accidental sampling techniques. Data analysis techniques used the chi-square statistical test and to determine the closeness of the relationship using the contingency coefficient test. The results obtained 12 people (33.3\%) had diabetic ulcers and 24 people (66.7\%) did not have diabetic ulcers. There are 9 people (25.0\%) with less knowledge, 12 people (33.3\%) with moderate knowledge and 15 people (41.7\%) with good knowledge. There is a relationship between the level of knowledge of patients with the incidence of diabetic ulcers in DM patients in Seruni Room Dr. M. Yunus Bengkulu. in the medium relationship category. It is expected that nurses can provide information and health education about Diabetes Mellitus and prevention of complications to patients and families.
\end{abstract}

Keywords: knowledge; diabetic ulcer; diabetes mellitus 


\section{LATAR BELAKANG}

Diabetes Melitus adalah penyakit yang ditandai dengan terjadinya hiperglikemia dan gangguan metabolisme karbohidrat, lemak, dan sekresi insulin dengan gejala polidipsia, poliuria, polifagia dan kesemutan. Estimasi terakhir Internasional Diabetes Federation (IDF) terdapat 425 juta orang yang hidup dengan diabetespada tahun 2017 yang terdiri dari 327 juta orang berada pada usia 20-64 tahun dan 98 juta juta orang berada pada usia 65-79 tahun. Pada tahun 2045 jumlah tersebut diperkirakan akan meningkat menjadi 629 juta orang yang terdri 438 juta orang berada pada usia 20-64 tahun dan 191 juta orang berada pada usia 65-79 tahun (IDF, 2017)

Diabetes melitus telah menjadi epidemik di amerika serikat dengan 21 juta orang (7\% dari populasi Amerika Serikat) yang menderita penyakit ini sekitar 15 juta orang didiagnosis menderita diabetes melitus dengan hampir 6 juta diperkirakan mengalami diabetes militus namun belum terdiagnosis (Black, 2009)

Indonesia termasuk dalam peringkat 6 angka kejadian diabetes melitus terbanyak di dunia. Dalam Diabetes Atlas 2000 (International Diabetes Federation) tercantum perkiraan penduduk Indonesia diatas 20 tahun sebesar 125 juta dan dengan asumsi prevalensi DM 4,6\%, diperkirakan pada tahun 2000 berjumlah 5,6 juta. Berdasarkan pola perambahan penduduk seperti ini, diperkirakan pada tahun 2020 nanti akan ada sejumlah 178 juta penduduk berusia diatas 20 tahun dan dengan asumsi prevalensi DM sebesar 4,6\% akan didapatkan $8,2 \%$ juta pasien diabetes. Temuan kasus diabetes melitus lebih banyak di daerah perkotaan dari pada di desa (Richardo, 2014).

Diabetes melitus adalah penyakit kronis dan progresif yang ditandai dengan ketidakmampuan tubuh untuk metabolisme karbohidrat, lemak dan protein yang menyebabkan hiperglikemia. Diabetes melitus kadang-kadang disebut sebagai gula tinggi diabetes mellitus dapat dikaitkan dengan komplikasi serius,namun penderita diabetes mellitus dapat mengambil tindakan pencegahan untuk mengurangi kemungkinan terjadinya kejadian tersebut. (Black, 2009)

Komplikasi mikro dan makroangiopati yang merupakan penanda awal kejadian komplikasi sering kali kurang dipahami dan kurang dianalisis oleh pasien DM. Di lain sisi progresivitas penyakit akibat DM ini baru dirasa setelah komplikasi yang timbul menyerang organ dan malfungsi organ yang muncul mengganggu proses homeostasis tubuh. Salah satu komplikasi yang penting dari DM adalah masalah kaki diabetes, dimana komplikasi merupakan masalah yang meningkat pada kesehatan masyarakat dan merupakan penyebab utama masuk, amputasi dan kematian pada pasien diabetes (Desalu, 2011)

Kurangnya pengetahuan atau kesadaran pasien sehingga pasien datang biasanya dalam keadaan gangren yang berat sehingga sering harus dilakukan amputasi selain itu kesadaran yang rendah pada masyarakat tersebut menjadi salah satu faktor yang berkontribusi terhadap tingginya angka kejadian ulkus diabetik di Indonesia. Dalam penatalaksanaan DM dikenal empat pilar pengelolaan Diabetes mellitus untuk meningkatkan pengetahuan dan pencegahannya yaitu dengan edukasi, nutrisi, aktivitas fisik, dan medikasi (PERKENI, 2011).

Bila seorang pasien mempunyai pengetahuan tentang risiko terjadinya ulkus diabetes, maka pasien akan dapat memilih alternatif yang terbaik bagi dirinya dan cenderung memperhatikan hal-hal yang penting tentang perawatan diabetes melitus seperti pasien akan melakukan pengaturan pola makan yang benar, berolah raga secara teratur, mengontrol kadar gula darah dan memelihara lingkungan agar terhindar dari benda-benda lain yang dapat menyebabkan luka. Apabila perawatan yang dilakukan dengan tepat maka dapat membantu proses penyembuhan dan diharapkan pasien menjadi sehat baik fisik, mental, sosial dan spiritual (Nurhasan, 2012).

Berdasarkan data medical record RSUD Dr. M. Yunus Bengkulu didapatkan jumlah pasien diabetes mellitus pada tahun 2015 sebanyak 355 orang dengan 32 orang yang 
mengalami ulkus diabetik, pada tahun 2016 sebanyak 359 orang dengan 29 orang yang mengalami ulkus diabetik dan pada tahun 2017 sebanyak 369 orang dengan 35 orang yang mengalami ulkus diabetik.Berdasarkan latar belakang tersebut, maka tujuan peneltian ini untuk hubungan tingkat pengetahuan pasien dengan kejadian ulkus diabetik pada pasien diabetes mellitus di Ruang Seruni RSUD Dr. M. Yunus Bengkulu.

\section{METODE}

Metode penelitian kuantatif dengan desain deskriptif korelasi yang menggunakan rancangan penelitian cross sectiona/Populasi dalam penelitian ini adalah seluruh pasien diabetes mellitus yang dirawat di Ruang Seruni RSUD Dr. M. Yunus Bengkulu pada bulan JuliAgustus 2018. Pengambilan sampel dalam penelitian ini menggunakan teknikAccidental sampling sebanyak 36 orang. Pengumpulan data dalam penelitian ini menggunakan data primer yang diperoleh dari wawancara dan penyebaran kuesioner kepada pasien diabetes mellitus yang dirawat di Ruang Seruni RSUD Dr. M. Yunus Bengkulu. Data sekunder diperoleh dari status pasien untuk melihat diagnosa yang diderita pasien. Analisis data dilakukan secara univariat, bivariat dengan Uji Chi-Square.

\section{HASIL}

Analisis univariat ini bertujuan untuk melihat gambaran masing-masing variabel baik variabelindependen (pengetahuan) dan variabel dependen (kejadian ulkus diabetikum), adapun hasil analisis univariat adalah:

Tabel 1.Distribusi frekuensi kejadian ulkus diabetik di Ruang Seruni RSUD Dr. M. Yunus Bengkulu

\begin{tabular}{ccc}
\hline UlkusDiabetikum & Frekuensi & $\begin{array}{c}\text { Presentasi } \\
(\%)\end{array}$ \\
\hline Ya & 12 & 33,3 \\
Tidak & 24 & 66,7 \\
\hline Total & 36 & 100,0
\end{tabular}

Berdasarkan tabel 1, disebutkan bahwa dari 36 orang pasien dengan diabetes mellitus terdapat 12 orang $(33,3 \%)$ mengalami ulkus diabetikum dan 24 orang $(66,7 \%)$ tidak mengalami ulkus diabetikum.

Tabel 2.Distribusfrekuensi tingkat pengetahuan pasien DM tentang ulkus diabetik di Ruang Seruni RSUD Dr. M. Yunus Bengkulu

\begin{tabular}{ccc}
\hline Pengetahuan & Frekuensi & $\begin{array}{c}\text { Presentasi } \\
(\%)\end{array}$ \\
\hline Kurang & 9 & 25,0 \\
Cukup & 12 & 33,3 \\
Baik & 15 & 41,7 \\
\hline Total & 36 & 100,0 \\
\hline
\end{tabular}

Berdasarkan tabel 2, disebutkan bahwa dari 36 orang pasien dengan diabetes mellitus terdapat 9 orang $(25,0 \%)$ dengan pengetahuan kurang, 12 orang $(33,3 \%)$ dengan pengetahun cukup dan 15 orang $(41,7 \%)$ dengan pengetahun baik.

Analisis Bivariat dilakukan untuk mengetahui hubungan antara variabel independen (pengetahuan) dan dependen (Ulkus diabetikum). Adapun hasil analisisnya dapat dilihat pada tabel sebagai berikut:

Tabel 3Hubungan tingkat pengetahuan dengan kejadian ulkus diabetikum pada pasien DM di Ruang Seruni RSUD Dr. M. Yunus Bengkulu

\begin{tabular}{|c|c|c|c|c|c|c|}
\hline \multirow[t]{2}{*}{ Pengetahuan } & \multicolumn{2}{|c|}{$\begin{array}{c}\text { UlkusDiabetik } \\
\text { um }\end{array}$} & \multirow[t]{2}{*}{ Total } & \multirow[t]{2}{*}{$x^{2}$} & \multirow[t]{2}{*}{$p$} & \multirow[t]{2}{*}{ C } \\
\hline & $\mathrm{Ya}$ & Tidak & & & & \\
\hline Kurang & 6 & 3 & 9 & \multirow{4}{*}{7,2} & \multirow{4}{*}{0,027} & \multirow{4}{*}{0,408} \\
\hline Cukup & 4 & 8 & 12 & & & \\
\hline Baik & 2 & 13 & 15 & & & \\
\hline Total & 12 & 24 & 36 & & & \\
\hline
\end{tabular}

Berdasarkan tabel diatas bahwa dari 9 orang dengan pengetahuan kurang terdapat 6 orang mengalami ulkus diabetikum dan 3 orang tidak mengalami ulkus diabetikum. Dari 12 orang dengan pengetahun sedang terdapat 4 orang mengalami ulkus diabetikum dan 8 orang tidak mengalami ulkus diabetikum. Dari 15 orang dengan pengetahuan baik terdapat 2 orang mengalami ulkus diabetikum dan 13 orang tidak mengalami ulkus diabetikum.

Hasil uji statistik Pearson Chi-Square didapatkan nilai $x^{2}=7,200$ dengan $p=0,027<0,05$ berarti signifikan, maka terdapat hubungan yang signifikan antara tingkat pengetahuan pasien dengan kejadian ulkus 
diabetik pada pasien diabetes mellitus di Ruang Seruni RSUD Dr. M. Yunus Bengkulu.

Hasil uji contingency coefficient didapat nilai $\mathrm{C}=0,408$ dengan $\mathrm{P}=0,027<0,05$ berarti signifikan. Nilai $\mathrm{C}=0,408$ tersebut dibandingkan dengan nilai $C_{\max }$. Jadi nilai $\frac{C}{C_{m}}=\frac{0,4}{0,7}=$ 0,58 , karena nilai ini terletak dalam interval 0,40-0,60 maka kategori hubungan sedang.

\section{PEMBAHASAN}

Berdasarkan tabel 1tampak bahwa dari 36 orang pasien dengan diabetes mellitus terdapat 12 orang $(33,3 \%)$ mengalami ulkus diabetikum dan 24 orang $(66,7 \%)$ tidak mengalami ulkus diabetikum. Berdasarkan hasil observasi saat penelitian data sebagian responden diabetes melitus kondisi lama ulkusnya rata-rata sudah menahun, dan penyebab ulkus karena adanya luka kecil yang tidak kunjung sembuh.

Hasil penelitian diatas sejalan dengan penelitian yang dilakukan oleh Nurhanifah (2017), tentang faktor-faktor yang berhubungan dengan ulkus kaki diabetik di Poliklinik Kaki Diabetik. Didapatkan hasil Hasil penelitian menunjukkan faktor durasi diabetes, usia dan sensasi merupakan faktor yang berhubungan dengan ulkus kaki diabetik. Sedangkan faktor denyut nadi perifer dan deformitas anatomi tidak berhubungan dengan ulkus kaki diabetik.

Berdasarkan tabel 2, tampak bahwa dari 36 orang pasien dengan diabetes mellitus terdapat 9 orang $(25,0 \%)$ dengan pengetahuan kurang, 12 orang $(33,3 \%)$ dengan pengetahun cukup dan 15 orang $(41,7 \%)$ dengan pengetahun baik. Kondisi ini menunjukkan sebagian besar responden dengan pengetahuan yang baik tentang diabetes mellitus, seperti responden mengerti gejala diabetes, pola makan yang baik untuk diabetes, jenis makanan yang dianjurkan, dan cara minum obat yang baik. Sedangkan responden yang memiliki pengetahuan kurang dan cukup rata-rata memiliki latar belakang pendidikan lulusan SD hingga SMA, dan saat dilakukan wawancara responden dengan pengetahuan kurang banyak yang tidak mengerti apa saja tanda gejala diabetes, pencegahannya, serta pola makan yang baik untuk pasien diabetes.
Hasil penelitian ini sejalan dengan penelitian yang dilakukan oleh Wulandini (2015), tentang hubungan pengetahuan penderita diabetes melitus terhadap kejadian luka diabetes melitus di Ruangan Penyakit Dalam RSUD Arifin Achmad Pekanbaru. Didapatkan hasil pengetahuan penderita Diabetes Melitus mayoritas tinggi 15 responden (51,7\%), dengan angka kejadian mayoritas tidak terjadi 20 responden (69,0\%). ( $p$ value $0,02<0,05$ Ini menunjukkan ada hubungan antara pengetahuan penderita Diabetes Melitus dengan kejadian luka Diabetes Melitus. Peneliti menyarankan kepada penderita Diabetes Melitus, agar selalu mencari informasi tentang Diabetes Melitus, upaya pencegahan terjadinya luka Diabetes Melitus.

Berdasarkan tabulasi silang antara tingkat pengetahuan pasien dengan kejadian ulkus diabetikum, tampak bahwa dari 9 orang dengan pengetahuan kurang terdapat 6 orang mengalami ulkus diabetikum. Kondisi ini menunjukkan bahwa pada responden dengan pengetahuan yang kurang akan lebih beresiko mengalami ulkus dabetikum, karena dengan pengetahuan yang kurang akan sulit dalam pembentukan perilaku pencegahan penyakit pada seseorang, karena reponden kurang mengetahui tentang penyakit yang dideritanya.

Dari responden dengan pengetahuan kurang terdapat 3 orang tidak mengalami ulkus diabetikum. Kondisi ni menunjukkan bahwa pada responden dengan pengetahuan yang kurang dapat memungkinkan untuk tidak terjad diabetes mellitus, hal ini dipengaruhi oleh bebrapa faktor seperti umur. Pada pasien dengan umur $<45$ tahun fungsi tubuh secara fisiologis belum mengalami penurunan sekresi atau resistensi insulin sehingga kemampuan fungsi tubuh terhadap pengendalian glukosa darah yang masih optimal.

Dari 12 orang dengan pengetahun sedang terdapat 4 orang mengalami ulkus diabetikum dan 8 orang tidak mengalami ulkus diabetikum. Dengan pengetahun yang cukup akan memperkecil resiko responden diabetes melitus mengalami ulkus diabetikum jika diikut oleh peran atau dukungan keluarga dalam membantu responden untuk patuh dengan 
program pengobatan pada pasien diabetes mellitus. Dukungan yang baik dari keluarga akan meningkatkan kewapadaan dan kepedulian responden terhadap resiko komplikasi yang akan dialami rensponden, sehingga akan membentuk sikap reponden dalam pencegahan terhadap komplikasi dibetes mellitus seperti ulkus diabetikum.

Dari 15 orang dengan pengetahuan baik terdapat 2 orang mengalami ulkus diabetikum. Pada responden dengan pengetahuan yang baik dapat memungkinkan untuk terjadi ulkus diabetikum. Hal ini disebabkan oleh usia reponden yang memasuki usia lansia seperti pada Tn. G dengan usia 63 tahun, selain itu faktor keturunan juga mampu mempengaruhi terjadinya ulkusdiabetikum, sehingga walaupun sudah memiliki pengetahuan baik juga masih dapat beresiko terjadi ulkus. Hasil penelitian ini sejalan teori Wapadji (2011), pada usia tua fungsi tubuh secara fisiologis menurun karena proses aging terjadi penurunan sekresi atau resistensi insulin sehingga kemampuan fungsi tubuh terhadap pengendalian glukosa darah yang tinggi kurang optimal.

Selain itu lama menderita penyait juga mempengaruhi terjadinya ulkus diabetikum seperti pada Ny. W yang mengatakan menderita penyakit diabetes mellitus $>10$ tahun. Hasil ini sejalan dengan pendapat Boyko (2012) pada penderita diabetes melitus yang telah menderita 10 tahun atau lebih, apabila kadar glukosa darah tidak terkendali, akan muncul komplikasi yang berhubungan dengan vaskuler sehingga mengakibatkan menurunnya sirkulasi darah dan adanya robekan atau luka pada kaki.

Dari responden dengan pengetahuan baik terdapat 13 orang tidak mengalami ulkus diabetikum. Hal ini menunjukkan bahwa dengan pengetahuan yang baik tentang pencegahan ulkus diabetikum akan mempengaruhi perilaku seseorang terhadap kesehatan sehingga akan mempermudah bagi reponden untuk melakukan pencegahan ulkus diabetikum, seperti dengan menjaga pola makan, mengkonsumsi obat rutin untuk menjaga kadar gula darah, dan melakukan perawatan pada area yang mudah terkena ulkus seperti pada area kaki.
Hasil uji statistik Pearson Chi-Square didapatkan hubungan yang signifikan antara tingkat pengetahuan pasien dengan kejadian ulkus diabetik pada pasien diabetes mellitus di Ruang Seruni RSUD Dr. M. Yunus Bengkulu. Hasil ini menunjukan bahwa pengetahuan memliki kontribusi yang penting pada resiko terjadinya ulkus diabetikum. Dengan pengetahuan yang baik akan membentuk sikap yang baik terhadap perilaku kesehatan sesorang dan sebaliknya dengan pengtahu yang rendah akan menyulitkan sesorang dalam melakukan pencegahan terhadap resiko komplikasi ulkus diabetikum.

Hasil ini didukung oleh teori menurut Karyoso (2014) pengetahuan tentang penyakit diabetes mellitus, sangat penting karena tidak hanya untuk memahami penyakit tersebut tetapi pasien dapat menentukan langkah-langkah yang perlu diambil dalam rangka mengurangi beratnya penyakit. Pengetahuan manusia dapat mengembangkan apa yang diketahui dan dapat mengatasi kebutuhan kelangsungan hidup, sehingga akan mempengaruhi seseorang dalam berperilaku terutama tentang kesehatan dan pencegahan penyakit.

Hasil uji contingency coefficient didapat katagori hubungannya adalah sedang. Hal ini disebabkan karena adanya faktor-faktor lain yang menyebabkan terjadinya ulkus dabetikum misalnya perilaku pasien DM. Pengetahuan tidak selalu menyebabkan perubahan perilaku. Pernyataan ini didukung oleh Notoadmodjo (2014) mengatakan, perilaku seseorang terhadap kesehatan ada 4 unsur pokok, yaitu perilaku terhadap sakit dan penyakit, perilaku terhadap sistem pelayanan kesehatan, perilaku terhadap makanan dan perilaku terhadap lingkungan kesehatan. Dari perilaku-perilaku diatas, seseorang bisa melakukan perilaku aktif yang berupa tindakan dan perilaku pasif yang berupa sikap. Selain itu, budaya dikenal sangat mempengaruhi perilaku

\section{KESIMPULAN DAN SARAN}

Berdasarkan hasil disebutkan bahwa 36 orang terdapat 12 orang $(33,3 \%)$ mengalami ulkus diabetikum dan 24 orang $(66,7 \%)$ tidak mengalami ulkus diabetikum. 36 orang terdapat 
9 orang $(25,0 \%)$ dengan pengetahuan kurang, 12 orang $(33,3 \%)$ dengan pengetahun sedang dan 15 orang $(41,7 \%)$ dengan pengetahuan baik, ada hubungan antara tingkat pengetahuan

\section{REFERENSI}

Adji, G. 2011. Buku Ajar Ilmu Penyakai Dalam. Jakarta : FKUI

Black, M. J. 2009. Medical-Surgcal Nursing: Clinical Management for positive outcome. 8th Editon. Singapora : Elsevier

Brunner, I \& Suddart, E. 2013. Buku Ajar Keperawatan Medikal Bedah Edisi 8. Jakarta : EGC

Bustan, M. 2007. Manajemen Pengendalan Penyakit Tidak Menular. Jakarta: Rineka Cipta

Desalu, O. 2011. Diabetic Foot Care: Self Reported Knowledge and Practice Among Patients Attendind Three Tertiary Hospital in Nigeria. Diakses pada tanggal 21 maret 2018, dari https://www.google.co.id/?gws rd=ssl\#q =Ghana+Medical+ Journalt+ Vol.45\%2C+ Number+2+June+2011

Effendi, A. T. 2015. Resistensi insulin. Jakarta: FKUI

Fauziyah, N. F. 2012. Hubungan Pengetahuan Pasien Diabetes Melitus Tipe 2 Tentang Risiko Terjadinya Ulkus Diabetik Dengan Kejadian Ulkus Diabetik di RSUD Dr. Moewardi. Diakeses pada tanggal 4 April 2018, dari http://eprints.ums.ac.id/ 22552/

Harjanto, N. 2013. Epidemiologi Dan Faktor Faktor Risiko Terjadinya Diabetes Melitus Tipe 2. Semarang: UNDIP

Hartini, S. 2009. Diabetes Siapa Takut, Panduan Lengkap untuk Diabetes, Keluarganya dan Profesional Medis. Jakarta: Penerbit Qanita

IDF. 2017. IDF Diabetes Atlas-8th Edition. Diakses pada tanggal 28 Februari 2018, dari http://www.diabetesatlas.org/

Irianto, K. 2014. Epidemologi Penyakit Menular dan Tidak Menular. Bandung: Alfabeta pasien dengan kejadian ulkus diabetik pada pasien diabetes mellitus di Ruang Seruni RSUD Dr. M. Yunus Bengkulu, dengan kategori hubungan

sedang.

Kartika, R.W. 2017. Pengelolaan Gangren Kaki Diabetetikum Vol.44 no.1. Continuing Medical Education. Di aksek pada tanggal 18 Mei 2017.

Karyoso, G. 2014. Dasar-dasar Patofisiologi Penyakit. Jakarta: Binarupa Aksara

Mansjoer, A. 2011. KapitaSelekta Kedokteran Edisi 1. Media Aesculapius : Jakarta

Masriadi. 2016. Epidemologi Penyakit Tidak Menular. Jakarta: Trans Info Media

Misnadiarly, W. 2012. Mencegah Penyakit Akibat Kegemukan dengan Asupan Nutrisi. Jakarta : PT. Roche Indonesia Xenical Division.

Notoatmodjo. 2014. IImu Perilaku Kesehatan. Jakarta: Rineka Cipta

Nurhasan. 2015. Kiat Melawan Penyakit. Yogyakarta : Pustaka Pelajar

Nurhanifah. 2017. Faktor-Faktor Yang Berhubungan Dengan Ulkus Kaki Diabetik Di Poliklinik Kaki Diabetik. Diakses pada tanggal 24 Juli 2018, dari https://journal.umbim.ac.id/index.php/he althy/article /view/67

PERKENI. 2011. Konsensus pengelolaandiabetes melitus tipe $2 d i$ indonesia. Semarang: PB PERKENI

Prabowo. 2011. Penatalaksanaan Diabetes Melitus Terpadu. Jakarta: FKUI

Priscilla, L. 2016. Buku Ajar Keperawatan Medikal Bedah: Gangguan Endokrin. Jakarta: EGC

Richardo. 2014. Analisis Faktor Resiko Penyebab Terjadinya Diabetes Melitus Tipe 2 Pada Wanita Usia Produktif Dipuskesmas Wawonasa. Diakses pada tanggal 28 Februari 2018, dari https://ejournal.unsrat.ac.id/index.php/eb iomedik/article/view/4554

Russel. 2011. Bebas Dari 6 Penyakit Paling Mematikan. Yogyakarta: MedPress 
Smeltzer. S.C, 2002. Buku Ajar Keperawatan Medikal Bedah. Jakarta:EGC

Sujono, R. S. 2013. Asuhan Keperawatan Pada Pasien Dengan Gangguan Eksokrin \& Endokrin Pada Pankreas. Yogyakarta: Graha IImuSunaryati, S. S. 2011. 14 Penyakit Paling Sering Menyerang dan Mematikan. Jogjakarta: Flash Books
Suyono. 2015. Buku Ajar ilmu penyakit dalam. Jakarta: FKUI

Waspadji. 2015. Kaki Dibetes: Praktik Dan Penatalaksanan. Yogyakarta: MedPress

Wulandini. 2013. Hubungan Pengetahuan Penderita Diabetes Melitus Terhadap Kejadian Luka Diabetes Melitusdi Ruangan Penyakit Dalam RSUD Arifin Achmad Pekanbaru Diakses pada tanggal 4 April 2018, dari http://jurnal.univrab.ac.id lindex.php /keperawatan /article/download /72/47 